\title{
Probable Lack of Seed Transmission of Sweet Potato Feathery Mottle Virus in Sweet Potato
}

\author{
Petra Wolters ${ }^{1}$, Wanda Collins ${ }^{1}$, and J.W. Moyer ${ }^{2}$ \\ North Carolina State University, Raleigh, NC 27695
}

Additional index words. dot-immunobinding assay, Ipomoea batatas

Abstract. The establishment of a sweet potato repository in Georgia that will eventually accept and distribute true seed of sweet potato [Ipomoea batatas (L.) Lam.] raised the question of seed transmission of viruses, especially of sweet potato feathery mottle virus (SPFMV). Seedlings obtained from virus-infected parent plants were free of viral infection. Examination of virus distribution in virus-infected plants determined that SPFMV was present in vegetative tissue, but not in reproductive organs, indicating that the probability of SPFMV transmission in sweet potato through seed is very low.

Sweet potato is an important crop in many areas of the world (Bouwkamp, 1985). The importance and potential this crop offers for future development have resulted in establishment of a sweet potato repository in Georgia that has just begun to collect plant material. Populations of seed of I. batatas and related species from other countries will be brought to the repository, since seeds are generally considered a disease-free method of importing plant material.

Generally, symptoms caused by viral infection have not been observed on leaves of sweet potato seedlings and it has been assumed that no virus transmission occurred through seed. However, symptoms of russet crack, caused by a strain of sweet potato feathery mottle virus (SPFMV), have been reported on seedling roots (Cadena-Hinojosa and Campbell, 1981). SPFMV is a widespread aphid-transmitted virus (Moyer, 1986)

Received for publication 10 Apr. 1989. Paper no. 12277 of the Journal Series of the North Carolina Agricultural Research Service, Raleigh, NC 276957643. Mention of a trademark or proprietary product does not constitute a guarantee or warranty of the product by N.C. State Univ., nor does it imply approval to the exclusion of other products that may be suitable. The cost of publishing this paper was defrayed in part by the payment of page charges. Under postal regulations, this paper therefore must be hereby marked advertisement solely to indicate this fact.

Dept. of Horticultural Science.

${ }^{2}$ Dept. of Plant Pathology. of the potyvirus group (Cadena-Hinojosa and Campbell, 1981). The purpose of our research was to determine whether SPFMV could be seed-transmitted, since this information is necessary to ensure that sweet potato seeds acquired and distributed by the repository are free of SPFMV.

Four types of plant material (Types 1-4) were tested for viruses using two procedures (Procedures 1 and 2). Seeds were acid-scarified for $20 \mathrm{~min}$, rinsed with water, and planted in rows $2.5 \mathrm{~cm}$ apart with $15 \mathrm{~cm}$ between rows in a sandy-loam ground bed. Clonal material was propagated in pots by stem cuttings $(15 \mathrm{~cm})$ taken from the field. Plants were fertilized regularly with a balanced fertilizer (Nutrileaf, 20N-20P-20K; Miller Chemicals Fertilizer, Hanover, Pa.) and watered as needed.

Type 1 plant material consisted of 100 seedlings from each of six parent plants. The female parent plants had been exposed to virus infection through several vegetative generations of field culture. Viral tests were conducted to ensure that female parents were infected, and, consequently, all seedlings originated from virus-infected plants.

Type 2 plants consisted of 190 open-pollinated seedlings established from seeds from Puerto Rico, simulating a seed population introduced from a foreign source.

Seedlings of Type 1 and Type 2 were grown in screencages (Lumite, mesh $32 \times 32$ ) to prevent virus transmission by insects, and were sprayed regularly for insects.
The seed for type 3 originated in Brazil (three clones), Nigeria (two clones), Puerto Rico (five clones), Taiwan (two clones), the Philippines (2 clones), Costa Rica (three clones), and Japan (two clones). Selections were grown for several years as clones in the field in North Carolina.

Type 4 plant material consisted of various parts of vines and flowers from known virusinfected sweet potato plants. Stamens and pistils of nine flowers from each of two clones, 79BM17 and W159, were used. Also, three seeds of clone 79BM17 were harvested and tested for presence of virus. Pedicels of flowers were divided in three parts to determine virus distribution through the pedicel.

Testing for presence of virus using Procedure 1 involved the dot-immunobinding assay (DIA) as adapted for SPFMV (Moyer, 1986). This is a rapid and sensitive method of detecting viral antigens applied to nitrocellulose membranes as spots of crude sap (Gumpf et al., 1984). Procedure 2 consisted of cleft-grafting scions of $I$. batatas onto the indicator plant I. setosa (Ker. ). Scions of $I$. batatas consisting of a single node, petiole, and leaf were taken from the proximal portion of the vines. From Type 4 plant material, scions consisting of stamen, pistil, pedicel, or seed were also taken. To expose cambial tissue, a straight cut was made on both sides of the scion. The first internode of the stock was slit vertically. The scion was inserted in the slit and secured with selfadhesive latex bandages. Graftings were done in duplicate.

Grafted stocks were stacked and covered with plastic bags in screencages shaded with newspapers. The plastic bags were removed after 7 days and shading was removed after 10 to 11 days. Rootstock were evaluated for symptom development ( $2 \frac{1 / 2}{2}$ to 3 weeks after grafting (Campbell et al., 1974) and assayed for SPFMV, using the DIA procedure.

None of the seedlings of Type 1 plant material were demonstrated to be infected when indexed using Procedures 1 and 2. All rootstock onto which scions of the female parent plants were grafted exhibited symptoms caused by SPFMV and indexed positive. This result suggests either that SPFMV is not transmitted from parent to progeny or that the percentage of progeny infected by seed transmission is extremely low and could not be detected in a population of 600 plants.

All Type 2 plants were determined to be free of virus as indexed by Procedures 1 and 
2. Ipomoea setosa is an indicator plant for sweet potato viruses other than SPFMV (Campbell, 1974), suggesting that other viruses inciting symptoms in I. setosa also may not be seed-transmitted or may be transmitted in an extremely low percentage of the progeny.

Type 3 plants all indexed positive for SPFMV infection, as expected, since they had been field-grown for at least 1 year. However, no symptoms other than those normally caused by SPFMV were observed on grafted plants, suggesting that no other viruses (as detectable on I. setosa) were present in the seeds.

Dot-immunobinding assays with various parts of vines and flowers (Type 4 plant material) showed SPFMV existence only in old leaves. In addition, symptom expression incited by SPFMV was found on I. setosa plants grafted with leaves and pedicels. No symptoms other than those from SPFMV were found. I. setosa plants onto which stamen, pistils, and seed were grafted did not show viral symptoms.

About 800 seedlings were tested in this experiment. No virus symptoms were detected, indicating that the percentage of seed transmission of virus, if it did occur, was $<0.125 \%$ (the detectable level in this study). This is not absolute proof that viruses are not seed-transmitted in sweet potatoes. However, the results suggest that if viruses are seed-transmitted in sweet potato, their incidence occurs only in an extremely low percentage of the progeny. Recently, investigations at the International Potato Center in Peru demonstrated that, of $2000 \mathrm{I}$. nil seedlings tested for SPFMV, $0.2 \%$ were virusinfected (L. Salazar, personal communication). This information suggests the possibility of a low percentage of seed transmission in I. nil.

The fact that SPFMV could be detected in the pedicels of infected plants, but not in reproductive organs, supports the conclusion that seed transmission would be infrequent.

\section{Literature Cited}

Bouwkamp, J.C. 1985. Sweet potato products: a natural resource for the tropics. CRC Press, Boca Raton, Fla.

Cadena-Hinojosa, M.A. and R.N. Campbell. 1981. Serologic detection of feathery mottle strains in sweet potatoes and Ipomoea incarnata. Plant Dis. 65:412-414

Campbell, R.N., D.H. Hall, and N.N. Mielinis. 1974. Etiology of sweet potato russet crack disease. Phytopathology 64:210-218.

Grumpf, D.J., W. Kositratana, and G.Y. Zheng. 1984. Dot-immunobinding assay for virus detection. Phytopathology 74:847.

Moyer, J.W. 1986. Serological detection of sweet potato feathery mottle virus in sweet potato. Phytopathology 76:1133. 